\title{
Influence of the contractor's payment method on the economic effectiveness of the construction project from the contractor's point of view
}

https://doi.org/10.1515/eng-2018-0055

Received May 01, 2018; accepted Jul 30, 2018

\begin{abstract}
The scope of the paper is the problem of the economic effectiveness of the construction project from the contractor's point of view. The two main construction contract types are taken under consideration: the unit price contract based on the bill of quantities and the lump sum contract.
\end{abstract}

The net present value (NPV) is adopted in this paper as the basic economic efficiency criterion of the construction project. The NPV of the project for the contractor is calculated here as the sum of all future monthly contractor's cash flows (both incoming and outgoing) discounted by using the monthly cost of contractor's capital invested into the project. For the cash flow calculations, two basic payment methods are considered, depending on the type of the contract: the monthly payments in the case of the unit price contract and the payments for the WBS (Work Breakdown Structure) billing elements in the case of the lump sum contract. The contractor's monthly cash flow analysis also makes it possible to determine the monthly cash requirements for the contractor to finance the works each month and the total cash requirement to finance the project as the whole. This allows the contractor to correctly plan the financing of the project depending on the type of contract and the payment method. Moreover, using the optimization techniques known in the scheduling theory, for example based on the priority rules as in the case of the RCSP, one may try to improve the economic effectiveness of the project or to lower the cash requirement for the project. However, as shown by the authors, it does not have bring the expected results in the case of the lump sum contract.

Keywords: Optimization, construction, scheduling, metaheuristic, $N P V$, simulation, economic efficiency

\section{Introduction}

Among many forms of remuneration of contractors, the most common practice on the Polish market is to conclude contracts for construction works aiming at constructing new buildings either based on lump sum system or cost reimbursement contracts-bill of quantities contracts. Currently lump sum contracts are more commonly used. This is due to the widespread belief that this form of financing is safer for the client. The economic effect of the application of the lump sum remuneration affects the profitability of construction projects from the contractor's point of view, and thus the way in which it influences the market prices for construction services. Construction services should be understood as both typical contracts and also "turn-key" projects which include design works, not directly related to construction works.

A commonly used profitability measure of the project is the economic value determined by NPV (Net Present Value), calculated on the basis of discounted cash flow streams. This topic was discussed by many researchers [1, $2,4-6,11]$. These studies provide valuable information on the influence of factors limiting financial resources available to the contractor. Authors formulated and addressed the problem of maximizing the $N P V$ despite the restricted availability of funds required to finance the contract in between invoicing periods [8-11]. The effectiveness of generic algorithm method in solving this type of optimization tasks has been also assessed. What was not compared so far is the economic effect of adopting a specific form of remuneration. The authors of this paper assume that the lump sum contracts are less favourable because their primary effect is a significant increase in the cost of the construction project. This assumption is based on the approach to optimize and maximize the NPV and stabilize cash flows, depending on the form of remuneration. Au-

Janusz Kulejewski: Warsaw University of Technology, Faculty of Civil Engineering, Warsaw, Poland 
thors prove, based on a numeric example, that such differences actually exist and when choosing a form of remuneration, one should take into account various parameters, not just the client's convenience due to a questionable reduction of risks and the presumed fixed price of the works.

The paper assumes a fixed amount of works, as well as a diversity of forms of remuneration and settling the cost of construction works. The cost estimate calculation is based on monthly accounting and payments, and in the case of lump sum contracts, payments would be made upon completion of agreed stages of the project and types of construction works. The calculation model takes into account maximizing the $N P V$ parameter despite limited financial resources, and a variety of payment models (monthly, after completion of stages and work packages) that are considered in cash flows financial tables. A probability of modification in the quantity of works up to $+-5 \%$, described by triangular probability distributions, was also taken into consideration. The effect of such modification was simulated and assessed in terms of its influence on the contractor's monthly demand for financial resources. This affects the risk margin included in the calculation of the procurement offer by the contractor, resulting with a higher price for construction works in case of the lump sum contracts financial model. For the contractor, it is a security measure of sorts included in the offered price, covering the possibility of financial losses resulting in a more expensive contract for the client when lump sum is considered.

\section{Calculation of financial parameters of construction project}

As the project progresses, the contractor spends periodically the funds dedicated to covering the direct and indirect costs of construction works, and receives instalments for selling those works according to the agreed plan. The difference between the incomes and the expenditures, settled at the end of every time period, constitutes the cash flow for this period.

In case of bill of quantities contract, settlement of works is made at regular intervals, most often at the end of each time period. This means that at the end of a given time period the contractor issues an invoice to the client, based upon the total cost of works performed in this period. Due to the fact that administrative procedures take time, this amount becomes an income at the end of one of the future time periods. If administrative procedures take no more than the length of a time period, cash flow in time period $n$ equals:

$$
C F_{n}=I F_{n}-O F_{n},
$$

where:

$n$ - a number of a given time period,

$I F_{n}$ - contractor's incomes within time period $n$ due to client's payments in this period,

$O F_{n}$ - expenditures incurred by the contractor within time period $n$.

It is assumed here that the contractor pays his obligations on time, therefore the expenditures incurred within the current period equal the total cost of construction works executed in this time period. The incomes within time period $n$ equal estimated value of construction works executed in time period $n-1$ :

$$
I F_{n}=\sum_{p \in A(n-1)\}} W_{p(n-1)} ;
$$

where:

$\mathrm{W}_{p(n-1)}-$ value of work $p$, executed time period $n-1$, $\{A(n-1)\}$ - subset of works executed time period $n-1$.

It is common practice in construction industry that a time period is represented by one month.

In the case of a lump sum contract, the regularity of payments is not obvious. The amount of work done (e.g. the volume of excavations) is not measured. If only the client is able to assess the percentage of completion of works, then payments can be made periodically on the monthly basis. However, the percentage assessment of the progress of works is very unreliable. Therefore, it is assumed here, that payments in a lump sum contract are made irregularly, only after completion of specific work packages, independent in technical or functional terms. These packages are called billing elements here. This means that in case of considered lump sum contract, the contractor bears costs each month, but an invoice may be issued only after the final completion of a given billing element. Since the billing elements form parts of the whole construction project, this payment method is denoted here as partial payment. Monthly cash flow in a lump sum contract is calculated as the difference between monthly incomes and monthly expenditures. However, in a given month there may be no incomes, until a given billing element is completed.

The value of a monthly cash flow $C F_{n}$ may be positive or negative. The positive value of $C F_{n}$, marked here as $C F_{n}^{+}$, indicates a financial surplus or a positive balance in the end of a given month. The negative value of $C F_{n}$, marked here as $C F_{n}^{-}$, indicates a shortage of funds in the end of a given month. This amount should have to be covered 
by the contractor within his own funds. Let $C F_{\max }=\max$ $\left(\left|C F_{n}^{-}\right|\right)$be the maximum absolute value of negative $C F_{n}$. The value of $C F_{\max }$ informs of a maximum monthly demand for funds to finance the works. Fig. 1 depicts sample curves of contractor's cumulative expenditures, client's cumulative payments and contractor's cumulative cash flow in the case of regular monthly payments. The contractor's cumulative expenditures are depicted by a piecewise continuous curve. The client's cumulative payments are depicted by a step function. The client's payments for the work completed are assumed to lag one period behind expenditures. Let TCF be the maximum absolute value of a negative cumulative cash flow. The value of TCF informs of a total demand for funds to finance the works.



Figure 1: Sample curves of contractor's cumulative expenditures, client's cumulative payments and contractor's cumulative cash flow in the case of regular monthly payments.

\section{Economical value of a construction project for the contractor}

The economic value of construction projects for contractors comprises of a sum of discounted cash flows (NPV), calculated as current value of cash flows reduced by the expenditures incurred for their acquisition:

$$
N P V=\sum_{n=1}^{N} \frac{C F_{n}}{(1+r)^{n}} ;
$$

where: $C F_{n}$ - cash flow at the end of current time period (month); $n$ - number of consecutive period;

$N$ - number of periods within duration of the whole project;

$r$-assumed return ratio of contractor capital (decimal).

\section{The optimization problem}

It is assumed here that the goal of optimization lies in designing two variants of construction schedules, providing alternatively:

- the maximization of the economical value of the project for the contractor,

- the minimization of the contractor's monthly demand for funds to finance the works.

Elicited schedules must consider technological relations between works and requirements related to deadlines agreed with the client. They also must assure profitability of a project for the contractor. Limitation of usage of renewable resources is omitted.

1. Objective functions:

- Maximization of economic value of the project:

$$
\text { Max : NPV }=\sum_{n=1}^{N} \frac{C F_{n}}{(1+r)^{n}} .
$$

- Minimization of monthly demand for funds:

$$
\text { Min }: C F_{\max }=\max \left(\left|C F_{n}^{-}\right|\right) \text {; }
$$

2. Constrains:

- construction begins in assumed zero time:

$$
s_{1}=0
$$

- no task can start before finishing of its predecessors:

$$
s_{j} \geq f_{i}, i \in\{\operatorname{Pred}(j)\}
$$

- the project cannot finish later that on agreed with client deadline:

$$
t \leq T
$$

- economic value of the project cannot be negative:

$$
N P V \geq 0 .
$$

In order to reduce the demand for funds, deconcentration of works should be considered. 
This can be achieved in two stages, determining in the first stage the order of execution of works using a given priority rule, and - in the second stage - the final start and finish dates of non-critical works, taking into account their time slacks.

As a result of using a selected priority rule, planned date of starting work $i$, which has lower priority, will be delayed in relation to its earliest starting date, resulting from a technological interdependence between works. This delay is caused by the fact that the original set of direct predecessors of task $i$, will be expanded by a specific task, that according to the agreed priority rule, gained priority in resource allocation over work $i$. Therefore, new organizational relations are added in the network model of the project. However, the existing technological relations have to be taken into account. Therefore, the final sequencing of tasks may differ significantly from that obtained directly upon sorting tasks according to a given priority rule.

It is worth noticing that if $K$ is a number of all possible additional relations agreed upon the selection of a priority rule, then the number of all possible results in the first stage of optimization equals $2^{K}$. In order to determine which additional relations are sufficient in order to obtain the optimal solution under the assumed constrains, binary variables $x_{k}$ are introduced, describing:

- for $x_{k}=1$ : the need of introducing additional organizational relation regarding predecessing and succession of works

- for $x_{k}=0$ : lack of such necessity.

In order to generate values of binary variables $x_{k}$ and finding an optimal solution, metaheuristic algorithms can be used, working according to the chosen strategy of searching $K$-dimensional range of results. As a representation of results of calculations in the form of construction schedule, a commonly used schedule generator in MS Excel software can be utilized, showing terms of for all the works with the network analysis model.

Calculations start with primary sequencing (sorting) of all tasks according to the selected priority rule. Such sequencing shows the workflow of the project realized with the use of the method of consecutive execution (activity after activity). Primary sequencing takes under consideration technological relations between tasks, resulting in a new order of works, differing from the initial plan.

When analyzing the final sequence of works, additional organizational relations (predecessor-successor) are introduced. The next step consists of using selected calculation algorithm in order to obtain the result of the analyzed case, i.e. a list of necessary additional relations, which under constraining conditions, are necessary for minimizing monthly demand for funds or maximizing the economic value of the construction project.

\section{Numerical example}

The project is represented by the Activity-on-Node network with finish-to-start relations with the first node indicating the beginning and the last node representing the finish of the project, Figure 2. Dummy activities $i=1$ and $i=16$ indicate the start and finish of the project.

The project deadline is $T=12$ months from the beginning of works. It is assumed, that works will start as soon as possible. The project schedule data are given in Table 1. Day means work day. Figure 3 depicts the resulting project baseline schedule. The time unit here is one work day.



Figure 2: Network diagram of the construction Project.

Table 1: The project schedule data.

\begin{tabular}{lcccc}
\hline Id. & Description & $\begin{array}{c}\text { Duration, } \\
\text { days }\end{array}$ & \multicolumn{2}{c}{ Earliest } \\
\cline { 3 - 5 } & & & $\begin{array}{c}\text { start, } \\
\text { day }\end{array}$ & $\begin{array}{c}\text { finish, } \\
\text { day }\end{array}$ \\
\hline 1 & & - & 0 & 0 \\
2 & Start & 10 & 0 & 10 \\
3 & Excavation & 17 & 10 & 27 \\
4 & Coundations & 7 & 27 & 34 \\
5 & Structure & 25 & 34 & 59 \\
6 & Roof structure & 33 & 59 & 92 \\
7 & Roof covering & 18 & 92 & 110 \\
8 & External Installations & 10 & 0 & 10 \\
9 & Foundation covering & 6 & 34 & 40 \\
10 & Partition walls & 49 & 59 & 108 \\
11 & Internal plasters & 24 & 108 & 132 \\
12 & Facade & 41 & 40 & 81 \\
13 & Internal installations & 10 & 108 & 118 \\
14 & Terrain architecture & 5 & 81 & 86 \\
15 & Painting & 5 & 132 & 137 \\
16 & Finish & - & 137 & 137 \\
\hline
\end{tabular}


Table 2: Financial data for the bill of quantities contract.

\begin{tabular}{|c|c|c|c|c|c|}
\hline Work item & Description & $\begin{array}{l}\text { Direct cost, } \\
\text { PLN }\end{array}$ & $\begin{array}{c}\text { Indirect cost, } \\
\text { PLN }\end{array}$ & $\begin{array}{c}\text { Total cost, } \\
\text { PLN }\end{array}$ & $\begin{array}{l}\text { Value, } \\
\text { PLN }\end{array}$ \\
\hline 2 & Excavation & 93700,00 & 18909,00 & 112609,00 & 120491,00 \\
\hline 3 & Foundations & 114666,00 & 23140,00 & 137805,00 & 147451,00 \\
\hline 4 & Cellars & 79742,00 & 16092,00 & 95832,00 & 102543,00 \\
\hline 5 & Structure & 542648,00 & 109506,00 & 652151,00 & 697805,00 \\
\hline 6 & Roof structure & 291537,00 & 58832,00 & 350369,00 & 374895,00 \\
\hline 7 & Roof covering & 996044,00 & 201002,00 & 1197045,00 & 1280839,00 \\
\hline 8 & External Installations & 52201,00 & 10534,00 & 62735,00 & 67126,00 \\
\hline 9 & Foundation covering & 13916,00 & 2808,00 & 16724,00 & 17895,00 \\
\hline 10 & Partition walls & 684509,00 & 138134,00 & 822641,00 & 880228,00 \\
\hline 11 & Internal plasters & 534966,00 & 107956,00 & 642923,00 & 687927,00 \\
\hline 12 & Facade & 400510,00 & 80823,00 & 481335,00 & 515027,00 \\
\hline 13 & Internal installations & 79091,00 & 15961,00 & 95051,00 & 101705,00 \\
\hline 14 & Terrain architecture & 64901,00 & 13097,00 & 77998,00 & 83457,00 \\
\hline 15 & Painting & 56589,00 & 11420,00 & 68008,00 & 72769,00 \\
\hline \multirow{2}{*}{\multicolumn{2}{|c|}{ Total }} & 4005020,00 & 808214,00 & 4813226,00 & 5150158,00 \\
\hline & & & & Contract price: & 5150158,00 \\
\hline
\end{tabular}



Figure 3: The project baseline schedule.

For the financial analysis it is assumed, that there is 21 work days/month, indirect cost for contractor is 5900 PLN/work day and profit is $7 \%$ of total costs (sum of direct and indirect costs). Assumed return ratio of contractor's capital is $r=0,83 \%$ per month. Since the duration of the project before optimization is 137 work days ( $\approx 7$ months), the total indirect cost before optimization is 808300 PLN. The indirect cost ratio is then $808300 / 4005019 \approx 0,2018$. Resulting financial data for the bill of quantities contract are given in Table 2.

For the lump sum contract, the work items listed in Table 1 were allocated to six bill elements, as shown in TTable 3. Financial data are based on those given for the work items in Table 2.

In the case of lump sum contract, if payments are made only after a given billing element is completed (as assumed here) and if the client's administrative procedures take no more than one month, then:
- the payment for the billing element I. Substructure is made in month 3 ,

- the payment for the billing element II. Structure is made in month 7 ,

- the payment for the billing element III. Installations is made in month 7 ,

- the payment for the billing element IV. Finishes is made in month 8 ,

- the payment for the billing element V. Facade is made in month 5 ,

- the payment for the billing element VI. Terrain is made in month 6.

Results of financial analysis for the baseline schedule are shown in Table 4. Figures 4 and 5 depict cumulative expenditures, cumulative incomes and cumulative cash flow for the contractor for the considered two types of contract. The time unit here is one month with the length of 21 work days.

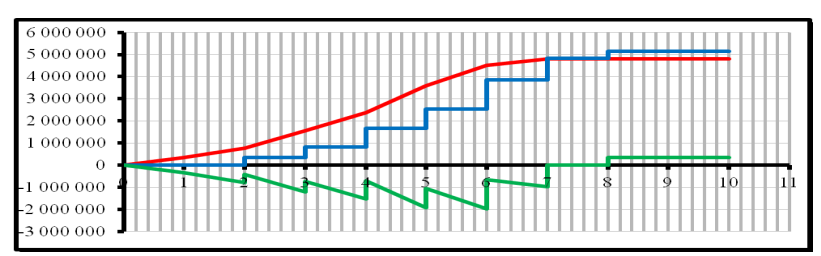

Figure 4: Contractor's cumulative expenditures, client's cumulative payments and contractor's cumulative cash flow in case of bill of quantities contract; based upon data given in Table 2 and Figure 3. 
Table 3: The billing elements for lump sum contract with the relevant financial data.

\begin{tabular}{lcccccc}
\hline Id & $\begin{array}{c}\text { Name of the } \\
\text { element }\end{array}$ & $\begin{array}{c}\text { Allocated work } \\
\text { items }\end{array}$ & $\begin{array}{c}\text { Direct cost, } \\
\text { PLN }\end{array}$ & $\begin{array}{c}\text { Indirect cost, } \\
\text { PLN }\end{array}$ & $\begin{array}{c}\text { Total cost, } \\
\text { PLN }\end{array}$ & $\begin{array}{c}\text { Value, } \\
\text { PLN }\end{array}$ \\
\hline I & Substructure & $2+3+4+8$ & 340309,00 & 68675,00 & 408981,00 & 437611,00 \\
II & Structure & $5+6+7+9$ & 1844145,00 & 372148,00 & 2216289,00 & 2371434,00 \\
III & Installations & 13 & 79091,00 & 15961,00 & 95051,00 & 101705,00 \\
IV & Finishes & $10+11+15$ & 1276064,00 & 257510,00 & 1533572,00 & 1640924,00 \\
V & Facade & 12 & 400510,00 & 80823,00 & 481335,00 & 515027,00 \\
VI & Terrain & 14 & 64901,00 & 13097,00 & 77998,00 & 83457,00 \\
\hline & Total & - & 4005020,00 & 808214,00 & 4813226,00 & 5150158,00 \\
& & & & Contract price: & 5150158,00 \\
\hline
\end{tabular}

Table 4: Results of financial analysis for the baseline schedule.

\begin{tabular}{ccc}
\hline Parameter & $\begin{array}{c}\text { Monthly payments } \\
\text { [PLN] } \\
\text { (Bill of quantities } \\
\text { contract) }\end{array}$ & $\begin{array}{c}\text { Partial payments } \\
\text { [PLN] }\end{array}$ \\
(Lump sum contract) \\
\hline Profit & 336932 & 336932 \\
$N P V$ & 284147 & 224763 \\
$C F_{\max }$ & 442785 & 1333255 \\
$T C F$ & 1973426 & 3783269 \\
\hline
\end{tabular}

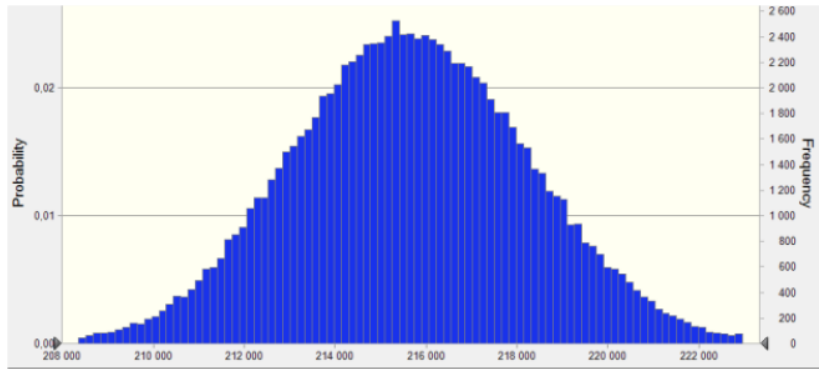

(a)

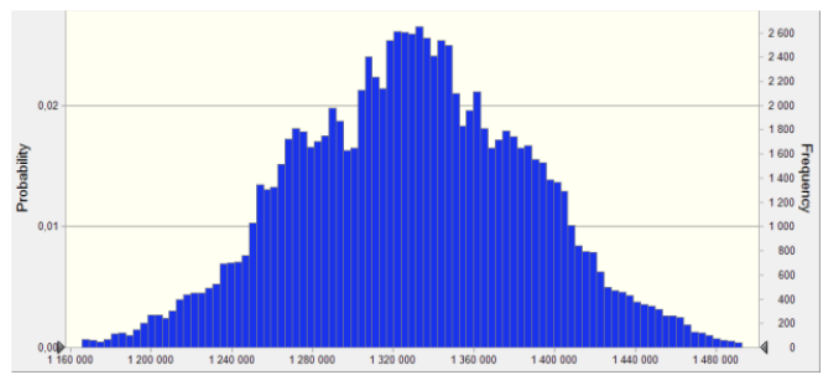

(b)

Figure 6: Sample simulation reports for the bill of quantity contract: a) project $N P V$, b) maximum monthly cash requirement $C F_{\max }$.

simulations was 100000. The results are given in Table 5 . Sample simulation reports for the bill of quantity contract are depicted on Figure 6.

Suppose now, that the optimization of financial parameters of construction project in case of a lump sum contract is considered, with the use of 6 selected priority rules: 1) priority for works with higher direct cost; 2) priority for works with lower direct cost; 3 ) priority for works with shorter total slack; 4) priority for works with earlier starting time; 5) priority for works with shorter duration; 6) priority for works with longer duration.

Results of the maximization of project NPV are given in Table 6. The best solutions are obtained with Priority rules 1 and 4. Solution obtained with priority rule 1 con- 
Table 5: Influence of random variations of works' quantities within $+-5 \%$ onto financial parameters of construction project.

\begin{tabular}{ccccccc}
\hline Parameter & \multicolumn{2}{c}{ Monthly payments (Bill of quantities contract) } & \multicolumn{2}{c}{ Partial payments (Lump sum contract) } \\
\cline { 2 - 7 } & $\begin{array}{c}\text { minimum } \\
\text { value }\end{array}$ & mean value & $\begin{array}{c}\text { maximum } \\
\text { value }\end{array}$ & $\begin{array}{c}\text { minimum } \\
\text { value }\end{array}$ & mean value & $\begin{array}{c}\text { maximum } \\
\text { value }\end{array}$ \\
\hline Total cost & $\mathbf{4 6 6 7 9 4 0}$ & $\mathbf{4 8 1 1 4 3 6}$ & $\mathbf{4 9 6 2 9 0 9}$ & $\mathbf{4 6 6 3 6 7 1}$ & $\mathbf{4 8 1 1 7 2 9}$ & $\mathbf{4 9 4 8 7 8 5}$ \\
$\begin{array}{c}\text { Contract } \\
\text { price }\end{array}$ & $\mathbf{4 9 9 4 6 9 6}$ & $\mathbf{5 1 4 8 2 3 6}$ & 5310313 & $\mathbf{5 1 4 8 2 3 6}$ & $\mathbf{5 1 4 8 2 3 6}$ & $\mathbf{5 1 4 8 2 3 6}$ \\
Profit & 326756 & $\mathbf{3 3 6 8 0 0}$ & 347404 & 201467 & $\mathbf{3 3 8 5 2 3}$ & 486580 \\
NPV & 275878 & $\mathbf{2 8 4 0 4 8}$ & 292763 & 97265 & $\mathbf{2 2 6 0 8 8}$ & 366407 \\
CF & 414290 & $\mathbf{4 4 7 0 2 5}$ & 587468 & 1093263 & $\mathbf{1 3 2 9 3 4 6}$ & 1607675 \\
TCF & 1894640 & $\mathbf{1 9 8 0 9 2 4}$ & 2130420 & 3633621 & $\mathbf{3 7 8 1 7 0 3}$ & 4189370 \\
\hline
\end{tabular}

Table 6: Results of the maximization of project NPV with selected priority rules.

\begin{tabular}{ccccccc}
\hline Parameter & \multicolumn{7}{c}{ Optimization criterion: maximization of NPV, priority rule: } \\
\cline { 2 - 7 } & 1 & 2 & 3 & 4 & 5 & 6 \\
\hline Profit & 336932 & 336932 & 336932 & 336932 & 336932 & 336932 \\
$N P V$ & $\mathbf{2 2 4 9 4 5}$ & 224763 & 224763 & $\mathbf{2 2 4 9 4 5}$ & 224763 & 226148 \\
$C F_{\max }$ & 1302056 & 1333255 & 1333255 & 1302056 & 1333255 & 1380055 \\
$T C F$ & 3886274 & 3783269 & 3783269 & 3886274 & 3783269 & 3783269 \\
Duration & 137 & 137 & 137 & 137 & 137 & 137 \\
(days) & & & & & & \\
\hline
\end{tabular}

sists in introducing additional dependence between activities 13 (predecessor) and 14 (successor). Figure 7 depicts the resulting project schedule. Figure 8 depicts the resulting curves of contractor's cumulative expenditures, client's cumulative payments and contractor's cumulative cash flow.

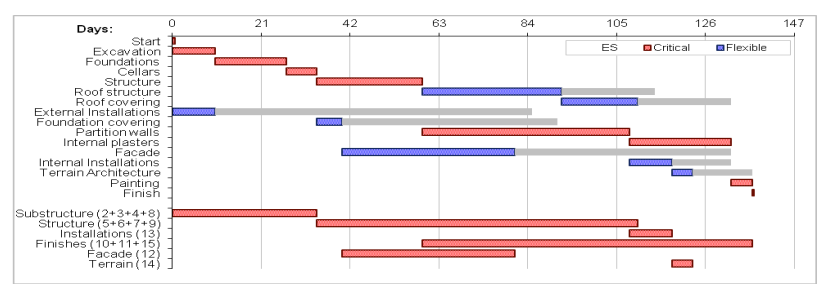

Figure 7: The project schedule for the maximization of project NPV with the priority for works with higher direct cost.

The solutions of optimization are as follows:

- for the Priority rule 1: additional dependences between activities 13 (predecessor) and 14 (successor),

- for the Priority rule 2: additional dependences between activities 4 (predecessor) and 8 (successor), 11 (predecessor) and 7 (successor),

- for the Priority rule 3: no solution with respect to the deadline $T=12$ months,

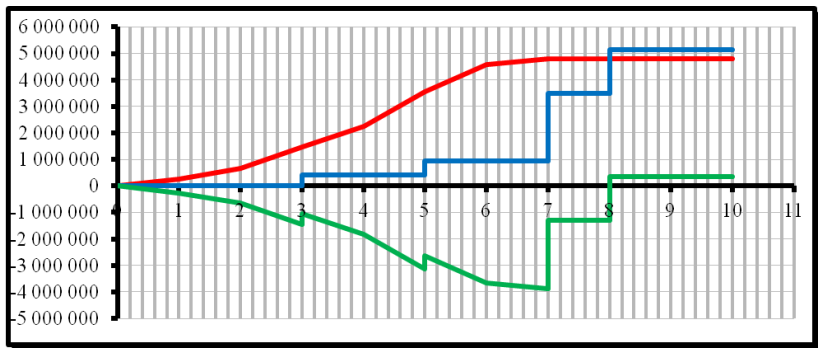

Figure 8: Contractor's cumulative expenditures, client's cumulative payments and contractor's cumulative cash flow for the maximization of project $N P V$ with the priority for works with higher direct cost.

- for the Priority rule 4: additional dependences between activities 2 (predecessor) and 8 (successor), 8 (predecessor) and 3 (successor), 12 (predecessor) and 6 (successor), 7 (predecessor) and 11 (successor),

- for the Priority rule 5: additional dependences between activities 9 (predecessor) and 5 (successor), 11 (predecessor) and 14 (successor),

- for the Priority rule 6: additional dependences between activities 3 (predecessor) and 8 (successor), 9 (predecessor) and 5 (successor), 10 (predecessor) and 11 (successor), 11 (predecessor) and 13 (successor). 
Table 7: Results for the minimization of $C F_{\max }$ with selected priority rules.

\begin{tabular}{ccccccc}
\hline Parameter & \multicolumn{5}{c}{ Optimization criterion: minimization of $C F_{\max }$, priority rule: } \\
\cline { 2 - 6 } & 1 & 2 & 3 & 4 & 5 & 6 \\
\hline Profit & 336932 & 230732 & 336932 & 136332 & 301532 & 224832 \\
$N P V$ & 224945 & 87094 & 224763 & 18113 & 199797 & 119044 \\
$C F_{\max }$ & 1302056 & 840213 & 1333255 & 721229 & 973848 & 897505 \\
$T C F$ & 3886274 & 3786464 & 3783269 & 3941363 & 3921674 & 3786869 \\
$\begin{array}{c}\text { Duration } \\
\text { (days) }\end{array}$ & 137 & 155 & 137 & 171 & 143 & 156 \\
\hline
\end{tabular}

Results of the minimization of $C F_{\max }$ are given in Table 7. The best solution is obtained with Priority rule 4 . Figure 9 depicts the resulting project schedule. Figure 10 depicts the resulting curves of contractor's cumulative expenditures, client's cumulative payments and contractor's cumulative cash flow.

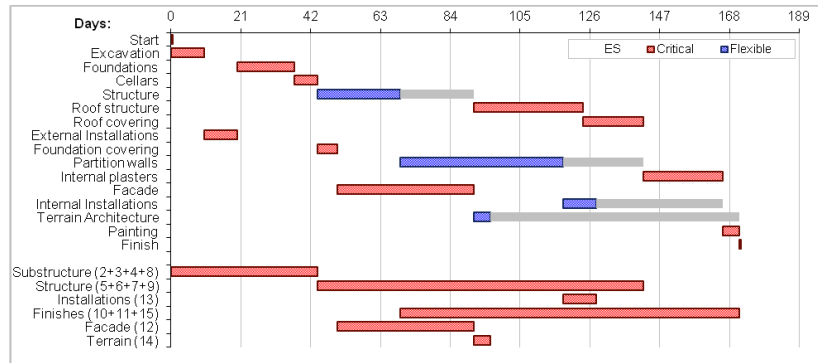

Figure 9: The project schedule for the minimization of $C F_{\max }$ with the Priority rule 4: priority for works with earlier starting time.

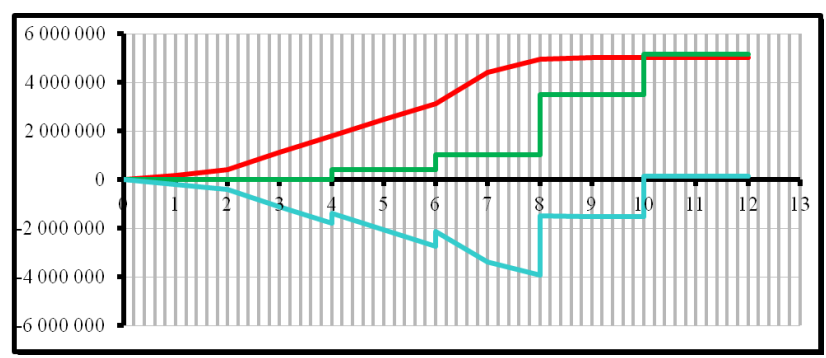

Figure 10: Contractor's cumulative expenditures, client's cumulative payments and contractor's cumulative cash flow for the minimization of $C F_{\max }$ with the priority for works with earlier starting time.

\section{Conclusion}

The results of the numerical example indicate, that the financial parameters of the considered construction project are more beneficial in the case of the bill of quantities contract, than in the lump sum contract with the partial payments based upon the billing elements.

The economic value of the project, calculated on the basis of the baseline schedule, is comparable for both contracts $(N P V=284147$ PLN for the bill of quantities contract and $N P V=224763$ PLN for the lump sum contract). However, the maximum monthly requirement for funds $C F_{\max }=1333255$ PLN is almost three times higher, and total demand for funds TCF $=3783269$ PLN is approximately two times higher in the case of the lump sum contract, compared to the bill of quantities contract $\left(C F_{\max }=\right.$ 442785 PLN and TCF = 1973426 PLN). This outcome did not changed upon the optimization of the schedule for the lump sum contract under chosen priority rules. In the case of maximization of $N P V$, the economic value of the project $N P V=224945$ PLN after maximization did not differ significantly from this calculated on the basis of the baseline schedule. The duration of the project remained unchanged. In the case of minimizing the monthly demand for funds, the value of $C F_{\max }=721229$ PLN for the best solution reduced twice compared to the value before optimization $C F_{\max }=1333255$ PLN. This reduction is the result of the strong deconcentration of works obtained on the basis of rule 4, causing the elongation of the project duration from 137 to 171 days (i.e., about 25\%). However, the reduced value of $C F_{\max }$ is still approximately twice higher, than the value of $C F_{\max }=442785$ PLN for the bill of quantities contract, calculated on the basis of the baseline schedule. Moreover, for this solution for the lump sum contract, $N P V$ drops drastically from 224763 PLN to 18113 PLN. This is the additional result of the elongation of the project duration, causing long periods of work without receiving payments for the completed billing elements. 
The lump sum contract with the partial payments based upon the billing elements proved to be unfavorable for the contractor also in the case of small, random changes of quantities of construction works. The variability of a quantity of each work within the range of $+-5 \%$ of its base value caused the variability of the economic value NPV of the lump sum project within the range from 97265 PLN up to 366407 PLN. The remedy could be the schedule of monthly payments, prepared by the contractor perhaps on the basis of optimization.

\section{References}

[1] Colak S., Agarwal A., Erenguc S., Multi-mode resourceconstrained project-scheduling problem with renewable resources: new solution approaches. Journal of Business \& Economics Research (Online), 2013, 11(11), 455

[2] Ibadov N., Fuzzy estimation of activities duration in construction projects, Archives of Civil Engineering, 2015, 61, 23-34, DOI: 10.1515/ace-2015-0012

[3] Kulejewski J., Zawistowski J., Metoda symulacyjna wyznaczania wielkości buforów stabilizujących harmonogramy budowlane, Budownictwo i Inżynieria Środowiska 2: 2011, 563-572

[4] Ranjbar M., De Reyck B., Kianfar F., A hybrid scatter search for the discrete time/resource trade-off problem in project scheduling, European Journal of Operational Research, 2009, 193(1), 3548
[5] Roston J., Porównanie algorytmów genetycznego i przeszukiwania tabu wykorzystanych do szeregowania zadań w budownictwie. Materiały Budowlane, 2016, DOI: 10.15199/33.2016.06.18

[6] Roston J., The multi-mode, resource-constrained project scheduling problem in construction: state of art review and research challenges, Technical Transactions, 2017, DOI: 10.4467/2353737XCT.17.070.6427

[7] Roston J., Zawistowski J., Construction projects' indicators improvement using selected metaheuristic algorithms, Procedia Engineering, 2016, 153, 595-598, https://doi.org/10.1016/ j.proeng.2016.08.198

[8] Al-Fawzan M.A., Haouari M.(2005). A bi-objective model for robust resource - constrained project scheduling. International Journal of Production Economics, Vol.96, No. 2, 175-187, Elsevier.

[9] Herroelen W., Van Dommelen P., Demeulemeester E.L.: Project network models with discounted cash flows - A guided tour through recent developments, European Journal of Operational Research, 100, 1 (1997) 97-121.

[10] Jaśkowski P., Biruk S.(2010):. Określanie buforów czasu w odpornych harmonogramach budowlanych. Zeszyty Naukowe WSOWL we Wroctawiu, Vol.3, No.157, 366-377, Wyższa Szkoła Oficerska Wojsk Lądowych we Wrocławiu, Wrocław.

[11] Özdamar L., Istanbul Kültür University, Department of Computer Engineering, Istanbul, Turkey. A heuristic treatment of tardiness and net present value criteria in resource constrained project scheduling, 1998. 